\title{
Design, Synthesis, Spectral Characterization and Antimicrobial Studies of Metals Based Nitrogen Donor Schiff Bases
}

\author{
Sajjad Hussain Sumrra ${ }^{1}$, Muhammad Ibrahim ${ }^{2, ~ *, ~ S a b a h a t ~ A m b r e e n ~}{ }^{3}$, Muhammad Imran ${ }^{4}$, \\ Muhammad Naveed Zafar ${ }^{5}$, Muhammad Faizan Nazar ${ }^{1}$, Fouzia Sultana Rehmani ${ }^{3}$ \\ ${ }^{1}$ Department of Chemistry, University of Gujrat, Gujrat, Pakistan \\ ${ }^{2}$ Department of Applied Chemistry, Govt. College University, Faisalabad, Pakistan \\ ${ }^{3}$ Department of Chemistry, University of Karachi, Karachi, Pakistan \\ ${ }^{4}$ Department of Chemistry, Ghazi University, Dera Ghazi Khan, Pakistan \\ ${ }^{5}$ Department of Chemistry, Quaid-e-Azam University, Islamabad, Pakistan
}

Email address:

ibrahim@gcuf.edu.pk (M. Ibrahim)

${ }^{*}$ Corresponding author

\section{To cite this article:}

Sajjad Hussain Sumrra, Muhammad Ibrahim, Sabahat Ambreen, Muhammad Imran, Muhammad Naveed Zafar, Muhammad Faizan Nazar, Fouzia Sultana Rehmani. Design, Synthesis, Spectral Characterization and Antimicrobial Studies of Metals Based Nitrogen Donor Schiff Bases. Journal of Drug Design and Medicinal Chemistry. Vol. 2, No. 3, 2016, pp. 26-34. doi: 10.11648/j.jddmc.20160203.11

Received: March 4, 2016; Accepted: June 3, 2016; Published: June 30, 2016

\begin{abstract}
A new series of bidentate nitrogen donor type Schiff bases $\left(\mathrm{L}^{1}\right)-\left(\mathrm{L}^{3}\right)$ were prepared by the condensation reaction of ethylene-1, 2-diamine with 3, 4, 6-trimethylacetophenone, 2-aminoacetophenone and 2, 4-dimethylacetophenone in 1:2 molar ratio. The ligands were further coordinated with $\mathrm{Co}(\mathrm{II}), \mathrm{Cu}(\mathrm{II}), \mathrm{Ni}(\mathrm{II})$ and $\mathrm{Zn}(\mathrm{II})$ metals to produce their new metal complexes having an octahedral geometry. These compounds were characterized on the basis of their physical, spectral and analytical data. Elemental analysis and spectral data of the uncomplexed ligands and their metal(II) complexes were found to be in good agreement with their structures, indicating high purity of all the newly synthesized compounds. All ligands and their metal complexes were screened for antimicrobial activity. The results of antimicrobial activity indicated that metal complexes have significantly higher activity compared to their corresponding ligands. This higher activity might be due to chelation process which reduces the polarity of metal ion by coordinating with ligands.
\end{abstract}

Keywords: Nitrogen Donor Schiff Bases, Bidentate Ligands, Metal(II) Complexes, Antibacterial and Antifungal Activities

\section{Introduction}

Metals based nitrogen and oxygen containing Schiff bases have been of great interest due to their extensive pharmacological activities [1]. It is well known that these nitrogen and oxygen donor ligands are involved in the chelation of the metals with their active sites [2]. Recently, coordination compounds of biologically active nature [3] have received much attention. Chelation introduces drastic changes in the biological properties of the ligands and their metal fraction [4]. It has been previously reported that many diseases have been cured by different chelating agents. A number of Schiff base metal complexes have been studied for biological activities like antibacterial [5], antifungal [6], antitumor [7], anticancer [8], anti-inflammatory [9], anticonvulsant [10], antiviral [11], ant iproliferative [12] and analgesic [13]. Similarly metal complexes of ethylene-1,2diamine are known to possess following biological activities such as antibacterial [14], antifungal [15], anticancer [16] and ant idiabetic [17]. In view of the significant structural, biological behavior and applications of ethylenediamine compounds, we wish to report the synthesis of a new class of Schiff bases $\left(\mathrm{L}^{1}\right)-\left(\mathrm{L}^{3}\right)$, derived from the reaction of ethylene1,2-diamine with 3,4,6-trimethylacetophenone, 2aminoacetophenone and 2,4-dimethylacetophenone respectively, and their $\mathrm{Co}(\mathrm{II}), \mathrm{Cu}(\mathrm{II}), \mathrm{Ni}(\mathrm{II})$ and $\mathrm{Zn}(\mathrm{II})$ metal 
complexes (1)-(12) (Scheme). The compounds were characterized on the basis of physical properties, elemental analysis, infrared and uv-visible spectra, and antimicrobial activities. The Schiff bases and their metal chelates were screened for in-vitro antibacterial activity against six bacterial strains; Escherichia coli, Streptococcus faecalis, Pseudomonas aeruginosa, Klebsiella pneumoniae, Staphylococcus aureus and Bacillus subtilis and in-vitro antifungal activity against six fungal strains; Trichophyton mentogrophytes, Epidermophyton floccosum, Aspergillus niger, Microscopum canis, Fusarium culmorum and Trichophyton schoenleinii. The antimicrobial results indicated that increased antimicrobial activity of Schiff bases against certain bacterial and fungal strains was due to chelation.

\section{Experimental}

\subsection{Materials and Methods}

Chemicals used were of analytical grade and purchased from commercial sources Sigma Aldrich and were used without further purification. All ligand synthesis reactions were carried out in solvents that were purified and dried before use, using standard literature methods. The redistilled and de-ionized water was used in all experiments. Gallenkamp apparatus was used to determine melting points of synthesized ligands and decomposition temperature of the metal complexes and were uncorrected. Infrared spectra of solids (in a $\mathrm{KBr}$ matrix) were recorded in the $3700-370 \mathrm{~cm}^{-1}$ region on a Nicolet FT-IR Impact 400D infrared spectrometer. ${ }^{1} \mathrm{H}$ and ${ }^{13} \mathrm{CNMR}$ spectra were run on a Bruker Advance $300 \mathrm{MHz}$ instrument. Mass spectrometry work was carried out by Ms. B. Woods N.U.I. Maynooth using an Agilent Technologies 6210 Time-of-Flight LC/MS. UV spectra were obtained on a Hitachi UV-3200 spectrophotometer. Microanalysis $(\mathrm{C}, \mathrm{H}$ and $\mathrm{N} \%$ ) of the synthesized compounds was carried out using a $\mathrm{CHN}$ Analyzer on Perkin Elmer 2400 series II. Molar conductances of the transition metal complexes were measured using an Inolab Cond 720 Conductivity Bridge at room temperature using 0.001 molar solutions in DMF. A Stanton SM12/S Gouy balance was used to measure the magnetic susceptibility of the metal complexes at room temperature using mercury acetate ligand as a standard.

\subsection{Chemistry of Synthesis of Ligands}

Different ketones such as 3,4,6-trimethylacetophenone, 2aminoacetophenone and 2,4-dimethylacetophenone in methanol $(20 \mathrm{~mL})$ were added to a refluxed solution of ethylene-1,2-diamine in same solvent in 1:2 molar ratio for 20 minutes followed by the few drops of $\mathrm{H}_{3} \mathrm{PO}_{4}$. The reaction mixture was refluxed for $6 \mathrm{~h}$ by monitoring through TLC. When the reaction was completed, it was cooled to room temperature, filtered and volume reduced to about one-third using rotary evaporator. The solid product thus obtained was filtered, washed with methanol and dried. It was recrystallized in hot methanol/ether $(2: 1)$. The same method was used for the preparation of ligands $\left(\mathrm{L}^{1}\right)-\left(\mathrm{L}^{3}\right)$.

$$
\text { Metal Complexes (9)-(12) of ( } \left.\mathrm{L}^{3}\right)
$$


$N, N^{\prime}$-bis[(1Z)-1-(2,3,5-trimethylphenyl)ethylidene] ethane1,2-diamine $\left(L^{1}\right)$

Yield $(2.43 \mathrm{~g}, 70 \%), \mathrm{mp} 201^{\circ} \mathrm{C}$; color reddish brown. ${ }^{1} \mathrm{H}$ NMR (ppm d ${ }_{6}$-DMSO) $2.18(\mathrm{~s}, 6 \mathrm{H}), 2.35$ (s, 18H), 3.82 (s, $4 \mathrm{H}), 6.75(\mathrm{~d}, 2 \mathrm{H}, \mathrm{J}=7.8 \mathrm{~Hz}), 7.14(\mathrm{~d}, 2 \mathrm{H}, \mathrm{J}=2.4 \mathrm{~Hz}) ;{ }^{13} \mathrm{C}$ NMR: (ppm d 6 -DMSO): 17.9, 18.2, 18.7, 21.6, 58.8, 127.6, $128.9,130.4,132.6,135.9,139.2,163.7$; IR $\left(\mathrm{KBr}, \mathrm{cm}^{-1}\right)$ : $1635(\mathrm{C}=\mathrm{N}), 1535,1498(\mathrm{C}=\mathrm{C})$; Mass Spectrum $(\mathrm{ESI})[\mathrm{M}]^{+}=$ 348.52. Anal. calcd. for $\mathrm{C}_{24} \mathrm{H}_{32} \mathrm{~N}_{2}$ (348.52): C, 82.71; H, 9.25; N, 8.04. Found: C, 82.67; H, 9.21; N, 8.01.

$N$, $N^{\prime}$-bis [(1Z)-1-(2-aminophenyl) ethylidene] ethane-1, 2diamine $\left(L^{2}\right)$

Yield $(2.11 \mathrm{~g}, 72 \%)$; mp $92{ }^{\circ} \mathrm{C}$; color dark brown. ${ }^{1} \mathrm{H}$ NMR (ppm d ${ }_{6}$-DMSO): $2.16(\mathrm{~s}, 6 \mathrm{H}), 3.87(\mathrm{~s}, 4 \mathrm{H}), 5.33(\mathrm{~s}, 4 \mathrm{H}$, $\left.\mathrm{NH}_{2}\right), 6.97(\mathrm{t}, 2 \mathrm{H}, \mathrm{J}=8.4 \mathrm{~Hz}), 7.05(\mathrm{~d}, 2 \mathrm{H}, \mathrm{J}=7.8 \mathrm{~Hz}), 7.39$ $(\mathrm{t}, 2 \mathrm{H}, \mathrm{J}=7.9 \mathrm{~Hz}), 7.67(\mathrm{~d}, 2 \mathrm{H}, \mathrm{J}=7.9 \mathrm{~Hz}) ;{ }^{13} \mathrm{C} \mathrm{NMR}:(\mathrm{ppm}$ $\mathrm{d}_{6}$-DMSO): $17.5,18.5,114.4,121.2,123.1,129.1,134.2$, 159.3, 162.9; IR $\left(\mathrm{KBr}, \mathrm{cm}^{-1}\right): 3250\left(\mathrm{NH}_{2}\right), 1635(\mathrm{C}=\mathrm{N}), 1532$, $1491(\mathrm{C}=\mathrm{C})$; Mass Spectrum (ESI): $[\mathrm{M}]^{+}=294.39$. Anal. calcd. for $\mathrm{C}_{18} \mathrm{H}_{22} \mathrm{~N}_{4}$ (294.39): C, 73.44; H, 7.53; N, 19.03. Found: C, 73.41; H, 7.50; N, 18.97 .

$N$, N'-bis[(1Z)-1-(2, 4-dimethylphenyl) ethylidene] ethane1, 2-diamine $\left(L^{3}\right)$

Yield (2.15 g, $68 \%$ ); mp: $112{ }^{\circ} \mathrm{C}$, color (yellow). ${ }^{1} \mathrm{H}$ NMR (ppm d d $\left.^{-D M S O}\right): 2.24(\mathrm{~s}, 6 \mathrm{H}), 2.32(\mathrm{~s}, 12 \mathrm{H}), 3.74(\mathrm{~s}, 4 \mathrm{H})$, 6.75 (dd, 2H, J = 7.9 Hz), 7.14 (d, 2H, J = 2.4 Hz), 7.37 (d, $2 \mathrm{H}, \mathrm{J}=7.9 \mathrm{~Hz}) ;{ }^{13} \mathrm{C}$ NMR (ppm d $\mathrm{d}_{6}$-DMSO): 17.5, 18.9, 20.9, 58.1, 126.7, 127.9, 131.1, 132.8, 136.3, 140.5, 162.9; IR $\left(\mathrm{KBr}, \mathrm{cm}^{-1}\right): 1633(\mathrm{C}=\mathrm{N}), 1535,1496(\mathrm{C}=\mathrm{C})$; Mass Spectrum (ESI): $[\mathrm{M}]^{+}=320.47$. Anal. calcd. for $\mathrm{C}_{22} \mathrm{H}_{28} \mathrm{~N}_{2}$ (320.47): $\mathrm{C}$, 82.45; H, 8.81; N, 8.74. Found: C, 82.41; H, 8.78; N, 8.71.

Chemistry of Synthesis of the Transition Metal(II) Complexes

A methanolic solution $(20 \mathrm{~mL})$ of respective metal(II) salt chloride. $\mathrm{nH}_{2} \mathrm{O}(5 \mathrm{mmol})$ was added $(\mathrm{n}=0,2$ or 6$)$ to hot magnetically refluxed methanolic solution $(20 \mathrm{~mL})$ of the respective Schiff base ligand $(10 \mathrm{mmol})$. The mixture was refluxed for $3 \mathrm{~h}$, during which a precipitated product was formed. It was then cooled to room temperature, filtered, washed with methanol and finally with diethyl ether. The precipitated product thus obtained was dried and recrystallized in a mixture of hot aqueous methanol (1:2) to obtain TLC pure product. All complexes were prepared according to the same above mentioned procedure.

NMR data of the Zn(II) complexes

$\left[\mathrm{Zn}\left(\mathrm{L}^{1}\right)_{2}\right](4){ }^{1} \mathrm{H}$ NMR (DMSO-d 6 , $\left.\delta, \mathrm{ppm}\right): 2.24(\mathrm{~s}, 6 \mathrm{H})$, $2.45(\mathrm{~s}, 18 \mathrm{H}), 3.92(\mathrm{~s}, 4 \mathrm{H}), 6.87(\mathrm{~d}, 2 \mathrm{H}), 7.28(\mathrm{~d}, 2 \mathrm{H}), 10.5$ (s, 4H, $\mathrm{H}_{2} \mathrm{O}$ ). ${ }^{13} \mathrm{C}$ NMR (DMSO- $\left.\mathrm{d}_{6}, \delta, \mathrm{ppm}\right): 18.6,18.8$, $19.6,21.9,59.9,128.1,129.5,130.9,132.9,136.8,139.9$, 164.4 .

$\left[\mathrm{Zn}\left(\mathrm{L}^{2}\right)_{2}\right](8){ }^{1} \mathrm{H}$ NMR (DMSO- $\left.\mathrm{d}_{6}, \delta, \mathrm{ppm}\right): 2.25(\mathrm{~s}, 6 \mathrm{H})$, $3.97(\mathrm{~s}, 4 \mathrm{H}), 5.39\left(\mathrm{~s}, \mathrm{NH}_{2}\right), 7.06(\mathrm{t}, 2 \mathrm{H}), 7.15(\mathrm{~d}, 2 \mathrm{H}), 7.47(\mathrm{t}$, $2 \mathrm{H}), 7.76(\mathrm{~d}, 2 \mathrm{H}), 10.5\left(\mathrm{~s}, 4 \mathrm{H}, \mathrm{H}_{2} \mathrm{O}\right) .{ }^{13} \mathrm{C} \mathrm{NMR}$ (DMSO- $\mathrm{d}_{6}$, $\delta$, ppm): 18.9, 114.8, 121.8, 123.7, 129.9, 134.6, 160.2, 163.9.

$\left[\mathrm{Zn}\left(\mathrm{L}^{3}\right)_{2}\right](12){ }^{1} \mathrm{H}$ NMR (DMSO-d $\left.6, \delta, \mathrm{ppm}\right): 2.34(\mathrm{~s}$,
$6 \mathrm{H}), 2.39(\mathrm{~s}, 12 \mathrm{H}), 3.84(\mathrm{~s}, 4 \mathrm{H}), 6.87(\mathrm{dd}, 2 \mathrm{H}), 7.22(\mathrm{~d}, 2 \mathrm{H})$, $7.45(\mathrm{~d}, 2 \mathrm{H}), 10.5\left(\mathrm{~s}, 4 \mathrm{H}, \mathrm{H}_{2} \mathrm{O}\right) .{ }^{13} \mathrm{C}$ NMR (DMSO- $\mathrm{d}_{6}, \delta$, ppm): 17.9, 19.7, 21.5, 58.8, 127.5, 128.4, 131.7, 133.3, $136.9,140.9,163.7$.

\subsection{Biological Activity}

\subsubsection{In-Vitro Antibacterial Activity}

All newly synthesized Schiff bases $\left(\mathrm{L}^{1}\right)-\left(\mathrm{L}^{3}\right)$ and their transition metal(II) complexes (1)-(12) were screened for their in-vitro antibacterial activity against (Escherichia coli, Streptococcus faecalis, Pseudomonas aeruginosa, Klebsiella pneumoniae, Staphylococcus aureus and Bacillus subtilis) bacterial strains by the agar-well diffusion method [18] and recorded in Table 3 . Small portion $(10 \mathrm{~mL})$ of nutrient broth was inoculated with the test organisms and incubated at $37^{\circ} \mathrm{C}$ for $24 \mathrm{~h}$. Using a sterile pipette, $0.6 \mathrm{~mL}$ of the broth culture of the test organism was added to $60 \mathrm{~mL}$ of molten agar which had been cooled to $45^{\circ} \mathrm{C}$, mixed well and poured into a sterile petri dish. Duplicate plates of each organism were prepared. The agar was allowed to set and harden and the required numbers of holes were cut using a sterile cork borer ensuring proper distribution of holes on the border and one in the center. Agar plugs were removed. Different cork borers were used for different test organisms. Using a $0.1 \mathrm{~mL}$ pipette, $100 \mu \mathrm{L}$ of the test sample dissolved in an appropriate solvent was poured into appropriately labelled cups. The same concentrations of the standard antibacterial agent (streptomycin in $1 \mathrm{mg} / \mathrm{mL}$ ) and the solvent (as control) were used. The plates were left at room temperature for $2 \mathrm{~h}$ to allow diffusion of the sample and incubated face upwards at $37^{\circ} \mathrm{C}$ for $24 \mathrm{~h}$. The diameter of the zones of inhibition was measured to the nearest $\mathrm{mm}$.

\subsubsection{In-Vitro Antifungal Activity}

Antifungal activities of all compounds were studied against six fungal strains Trichophyton mentogrophytes, Epidermophyton floccosum, Aspergillus niger, Microscopum canis, Fusarium culmorum and Trichophyton schoenleinii according to recommended procedure [19] and recorded in Table 4. Test sample was dissolved in sterile DMSO to serve as stock solution. Sabouraud dextrose agar was prepared by mixing Sabouraud 4\% glucose agar and agar agar in distilled water. It was then stirred with a magnetic stirrer to dissolve it and a known amount was dispensed into screw capped test tubes. Test tubes containing media were autoclaved at $121^{\circ} \mathrm{C}$ for $15 \mathrm{~min}$. Tubes were allowed to cool to $50^{\circ} \mathrm{C}$ and the test sample of desired concentrations pipetted from the stock solution into the non-solidified Sabouraud agar media. Tubes were then allowed to solidify in a slanting position at room temperature. Each tube was inoculated with a $4 \mathrm{~mm}$ diameter piece of inoculum removed from a seven day old culture of fungi.

\subsection{Minimum Inhibitory Concentration (MIC)}

Compounds containing promising antibacterial activity were selected for minimum inhibitory concentration (MIC) 
studies [20]. The minimum inhibitory concentration was determined using the disc diffusion technique by preparing discs containing $10,25,50$ and $100 \mu \mathrm{g} \mathrm{ml}^{-1}$ concentrations of the compounds along with standards at the same concentrations.

\section{Results and Discussion}

The condensation reaction of ethylene-1, 2-diamine with 3,4,6-trimethylacetophenone, 2-aminoacetophenone and 2,4-dimethylacetophenone in 1:2 molar ratio afforded three Schiff base ligands $\left(\mathrm{L}^{1}\right)-\left(\mathrm{L}^{3}\right)$ (Scheme). These ligands were air and moisture stable compounds. All of them were colored compounds. These were microcrystalline solids which melted at $92-202{ }^{\circ} \mathrm{C}$. All were soluble in DMSO and $\mathrm{DMF}$ at room temperature and soluble on heating in methanol and ethanol. These bidentate ligands reacted readily with $\mathrm{Co}(\mathrm{II}), \mathrm{Cu}(\mathrm{II}), \mathrm{Ni}(\mathrm{II})$ and $\mathrm{Zn}(\mathrm{II})$ metals as their chlorides $\left[\mathrm{CoCl}_{2} \cdot 6 \mathrm{H}_{2} \mathrm{O}, \mathrm{NiCl}_{2} \cdot 6 \mathrm{H}_{2} \mathrm{O}, \mathrm{CuCl}_{2} \cdot 2 \mathrm{H}_{2} \mathrm{O}\right.$ and $\mathrm{ZnCl}_{2}$ ] in methanol to form their metal(II) complexes (Scheme). All the synthesized metal(II) complexes were intensely colored except $\mathrm{Zn}$ (II) complexes which were white and all complexes were microcrystalline in nature. The metal(II) complexes decomposed without melting. They were all insoluble in common organic solvents such as ethanol, methanol, dichloromethane and acetone but soluble in DMSO and DMF. The spectral data and elemental analysis of the prepared ligands and their metal(II) complexes were in good agreement with their structure, indicating the high purity of all the compounds. The analytical data of the complexes indicated a 1:2 metal: ligand stoichiometry.

Table 1. Physical Measurements and Analytical Data of Metal(II) Complexes (1)-(12).

\begin{tabular}{|c|c|c|c|c|c|c|c|c|}
\hline \multirow{2}{*}{ No. } & \multirow{2}{*}{ Structure } & \multirow{2}{*}{ Yield (\%) } & \multirow{2}{*}{ MW/ Formula } & \multirow{2}{*}{ M.P $\left({ }^{\circ} \mathrm{C}\right)$} & \multicolumn{4}{|c|}{ Elemental Analysis (\%) Calc (Found) } \\
\hline & & & & & $\mathrm{C}$ & $\mathrm{H}$ & $\mathbf{N}$ & M \\
\hline (1) & {$\left[\mathrm{Co}\left(\mathrm{L}^{1}\right)_{2}\right]$} & 76 & {$[792.01] \mathrm{C}_{48} \mathrm{H}_{68} \mathrm{~N}_{4} \mathrm{O}_{2} \mathrm{Co}$} & $219-221$ & $\begin{array}{l}72.79 \\
(72.65)\end{array}$ & $\begin{array}{l}8.65 \\
(8.61)\end{array}$ & $\begin{array}{l}7.07 \\
(7.03)\end{array}$ & $\begin{array}{l}7.44 \\
(7.38)\end{array}$ \\
\hline (2) & {$\left[\mathrm{Ni}\left(\mathrm{L}^{1}\right)_{2}\right]$} & 71 & [791.77] $\mathrm{C}_{48} \mathrm{H}_{68} \mathrm{~N}_{4} \mathrm{O}_{2} \mathrm{Ni}$ & $237-239$ & $\begin{array}{l}72.81 \\
(72.72)\end{array}$ & $\begin{array}{l}8.66 \\
(8.59)\end{array}$ & $\begin{array}{l}7.08 \\
(7.02)\end{array}$ & $\begin{array}{l}7.41 \\
(7.35)\end{array}$ \\
\hline (3) & {$\left[\mathrm{Cu}\left(\mathrm{L}^{1}\right)_{2}\right]$} & 75 & [796.62] $\mathrm{C}_{48} \mathrm{H}_{68} \mathrm{~N}_{4} \mathrm{O}_{2} \mathrm{Cu}$ & 249- 251 & $\begin{array}{l}72.37 \\
(72.32)\end{array}$ & $\begin{array}{l}8.60 \\
(8.55)\end{array}$ & $\begin{array}{l}7.03 \\
(6.99)\end{array}$ & $\begin{array}{l}7.98 \\
(7.93)\end{array}$ \\
\hline (4) & {$\left[\mathrm{Zn}\left(\mathrm{L}^{1}\right)_{2}\right]$} & 77 & {$[604.22] \mathrm{C}_{48} \mathrm{H}_{68} \mathrm{~N}_{4} \mathrm{O}_{2} \mathrm{Zn}$} & $239-241$ & $\begin{array}{l}72.20 \\
(72.11)\end{array}$ & $\begin{array}{l}8.58 \\
(8.52)\end{array}$ & $\begin{array}{l}7.02 \\
(6.98)\end{array}$ & $\begin{array}{l}8.19 \\
(8.15)\end{array}$ \\
\hline (5) & {$\left[\mathrm{Co}\left(\mathrm{L}^{2}\right)_{2}\right]$} & 75 & {$[683.75] \mathrm{C}_{36} \mathrm{H}_{48} \mathrm{~N}_{8} \mathrm{O}_{2} \mathrm{Co}$} & $231-233$ & $\begin{array}{l}63.24 \\
(63.16)\end{array}$ & $\begin{array}{l}7.08 \\
(7.03)\end{array}$ & $\begin{array}{l}16.39 \\
(16.33)\end{array}$ & $\begin{array}{l}8.62 \\
(8.58)\end{array}$ \\
\hline (6) & {$\left[\mathrm{Ni}\left(\mathrm{L}^{2}\right)_{2}\right]$} & 73 & {$[683.51] \mathrm{C}_{36} \mathrm{H}_{48} \mathrm{~N}_{8} \mathrm{O}_{2} \mathrm{Ni}$} & $235-237$ & $\begin{array}{l}63.26 \\
(63.17)\end{array}$ & $\begin{array}{l}7.08 \\
(7.05)\end{array}$ & $\begin{array}{l}16.39 \\
(16.32)\end{array}$ & $\begin{array}{l}8.59 \\
(8.54)\end{array}$ \\
\hline (7) & {$\left[\mathrm{Cu}\left(\mathrm{L}^{2}\right)_{2}\right]$} & 80 & {$[688.36] \mathrm{C}_{36} \mathrm{H}_{48} \mathrm{~N}_{8} \mathrm{O}_{2} \mathrm{Cu}$} & $245-247$ & $\begin{array}{l}62.81 \\
(62.72)\end{array}$ & $\begin{array}{l}7.03 \\
(6.97)\end{array}$ & $\begin{array}{l}16.28 \\
(16.22)\end{array}$ & $\begin{array}{l}9.23 \\
(9.19)\end{array}$ \\
\hline (8) & {$\left[\mathrm{Zn}\left(\mathrm{L}^{2}\right)_{2}\right]$} & 75 & {$[690.23] \mathrm{C}_{36} \mathrm{H}_{48} \mathrm{~N}_{8} \mathrm{O}_{2} \mathrm{Zn}$} & $223-225$ & $\begin{array}{l}62.64 \\
(62.58)\end{array}$ & $\begin{array}{l}7.01 \\
(6.97)\end{array}$ & $\begin{array}{l}16.23 \\
(16.18)\end{array}$ & $\begin{array}{l}9.48 \\
(9.42)\end{array}$ \\
\hline (9) & {$\left[\mathrm{Co}\left(\mathrm{L}^{3}\right)_{2}\right]$} & 70 & {$[735.90] \mathrm{C}_{44} \mathrm{H}_{60} \mathrm{~N}_{4} \mathrm{O}_{2} \mathrm{Co}$} & $227-229$ & $\begin{array}{l}71.81 \\
(71.75)\end{array}$ & $\begin{array}{l}8.22 \\
(8.18)\end{array}$ & $\begin{array}{l}7.61 \\
(7.58)\end{array}$ & $\begin{array}{l}8.01 \\
(7.98)\end{array}$ \\
\hline (10) & {$\left[\mathrm{Ni}\left(\mathrm{L}^{3}\right)_{2}\right]$} & 81 & {$[735.67] \mathrm{C}_{44} \mathrm{H}_{60} \mathrm{~N}_{8} \mathrm{O}_{2} \mathrm{Ni}$} & $213-215$ & $\begin{array}{l}71.84 \\
(71.77)\end{array}$ & $\begin{array}{l}8.22 \\
() 8.19\end{array}$ & $\begin{array}{l}7.62 \\
(7.59)\end{array}$ & $\begin{array}{l}7.98 \\
(7.95)\end{array}$ \\
\hline (11) & {$\left[\mathrm{Cu}\left(\mathrm{L}^{3}\right)_{2}\right]$} & 78 & {$[740.52] \mathrm{C}_{44} \mathrm{H}_{60} \mathrm{~N}_{4} \mathrm{O}_{2} \mathrm{Cu}$} & $239-241$ & $\begin{array}{l}71.36 \\
(71.32)\end{array}$ & $\begin{array}{l}8.17 \\
(8.15)\end{array}$ & $\begin{array}{l}7.57 \\
(7.55)\end{array}$ & $\begin{array}{l}8.58 \\
(8.53)\end{array}$ \\
\hline (12) & {$\left[\mathrm{Zn}\left(\mathrm{L}^{3}\right)_{2}\right]$} & 76 & $\begin{array}{l}{[742.38]} \\
\mathrm{C}_{44} \mathrm{H}_{60} \mathrm{~N}_{4} \mathrm{O}_{2} \mathrm{Zn}\end{array}$ & $253-255$ & $\begin{array}{l}71.19 \\
(71.11)\end{array}$ & $\begin{array}{l}8.15 \\
(8.12)\end{array}$ & $\begin{array}{l}7.55 \\
(7.51)\end{array}$ & $\begin{array}{l}8.81 \\
(8.75)\end{array}$ \\
\hline
\end{tabular}

\section{IR Spectra}

Some of the characteristic IR peaks are reported in experimental part. The Schiff bases $\left(\mathrm{L}^{1}\right)-\left(\mathrm{L}^{3}\right)$ showed the characteristic azomethine $(\mathrm{C}=\mathrm{N})$ stretching [21] at 1633$1635 \mathrm{~cm}^{-1}$, hence giving clue of condensation product. The ligand $\left(\mathrm{L}^{2}\right)$ displayed band at $3250 \mathrm{~cm}^{-1}$ resulting from $\mathrm{NH}_{2}$ vibrations [22]. The comparison of the IR spectra of the Schiff bases $\left(\mathrm{L}^{1}\right)-\left(\mathrm{L}^{3}\right)$ with their metal(II) complexes (1)(12) indicated that the Schiff bases were principally coordinated to the metal(II) ions bidentately. The vibrations of azomethine group appearing in the spectra of metal(II) complexes shifted to lower frequency $\left(13-20 \mathrm{~cm}^{-1}\right)$ at 1615 $1622 \mathrm{~cm}^{-1}$ indicating the coordination of the azomethine nitrogen [23] with the metal(II) atoms. IR bands at 3250 $\mathrm{cm}^{-1}$ resulting from $\mathrm{NH}_{2}$ vibrations of ligand $\left(\mathrm{L}^{2}\right)$ remained unchanged in the complexes showing their non involvement in the coordination. The following evidences further support the mode of chelation:

- Appearance of the new bands at $533-549 \mathrm{~cm}^{-1}$ assigned to $v(\mathrm{M}-\mathrm{N})$ vibrations [24] in their metal complexes and were absent in their ligands.

- All the metal(II) complexes displayed [25] N new broad peaks at $3468-3478 \mathrm{~cm}^{-1}$ which were assigned to water molecules.

These new bands were only observed in the spectra of the complexes but absent in the spectra of the Schiff bases. Therefore, these clues supported the evidence of the participation of azomethine-N in the coordination. All these evidences compromise with the complexation of the metal(II) ions to the prepared Schiff bases. 
Table 2. Conductivity, Magnetic and Spectral Data of Metal(II) Complexes (1)-(12).

\begin{tabular}{lllll}
\hline No & $\boldsymbol{\Omega}_{\mathbf{M}}\left(\mathbf{\Omega}^{-1} \mathbf{c m}^{2} \mathbf{m o l}^{-1}\right)$ & $\mathbf{B . M} \boldsymbol{\mu}_{\text {eff }}$ & $\boldsymbol{\lambda}_{\mathbf{m}}\left(\mathbf{c m}^{-\mathbf{1}}\right)$ & IR $\left(\mathbf{c m}^{-1}\right)$ \\
\hline$(1)$ & 13.1 & 4.53 & 8667,17796 and 29674 & $3468\left(\mathrm{H}_{2} \mathrm{O}\right), 1622(\mathrm{C}=\mathrm{N}), 533(\mathrm{M}-\mathrm{N})$ \\
$(2)$ & 13.9 & 3.49 & $8659,17694,25716$ and 29767 & $3470\left(\mathrm{H}_{2} \mathrm{O}\right), 1621(\mathrm{C}=\mathrm{N}), 545(\mathrm{M}-\mathrm{N})$ \\
$(3)$ & 14.2 & 1.95 & 8705,17437 and 29673 & $3475\left(\mathrm{H}_{2} \mathrm{O}\right), 1623(\mathrm{C}=\mathrm{N}), 543(\mathrm{M}-\mathrm{N})$ \\
$(4)$ & 14.3 & Dia & 28715 & $3478\left(\mathrm{H}_{2} \mathrm{O}\right), 1615(\mathrm{C}=\mathrm{N}), 538(\mathrm{M}-\mathrm{N})$ \\
$(5)$ & 13.8 & 4.41 & 8627,17859 and 29674 & $3469\left(\mathrm{H}_{2} \mathrm{O}\right), 1622(\mathrm{C}=\mathrm{N}), 533(\mathrm{M}-\mathrm{N})$ \\
$(6)$ & 14.8 & 3.33 & $8685,17679,25746$ and 29791 & $3472\left(\mathrm{H}_{2} \mathrm{O}\right), 1620(\mathrm{C}=\mathrm{N}), 540(\mathrm{M}-\mathrm{N})$ \\
$(7)$ & 15.1 & 1.89 & 8735,17517 and 29731 & $3476\left(\mathrm{H}_{2} \mathrm{O}\right), 1620(\mathrm{C}=\mathrm{N}), 549(\mathrm{M}-\mathrm{N})$ \\
$(8)$ & 13.9 & Dia & 28755 & $3477\left(\mathrm{H}_{2} \mathrm{O}\right), 1618(\mathrm{C}=\mathrm{N}), 535(\mathrm{M}-\mathrm{N})$ \\
$(9)$ & 13.8 & 4.36 & 8699,17736 and 29744 & $3468\left(\mathrm{H}_{2} \mathrm{O}\right), 1620(\mathrm{C}=\mathrm{N}), 539(\mathrm{M}-\mathrm{N})$ \\
$(10)$ & 14.7 & 3.57 & $8639,17679,25771$ and 29816 & $\left.3471\left(\mathrm{H}_{2} \mathrm{O}\right), 1619(\mathrm{C}=\mathrm{N}), 535 \mathrm{M}-\mathrm{N}\right)$ \\
$(11)$ & 15.2 & 1.91 & 8670,17543 and 29713 & $3473\left(\mathrm{H}_{2} \mathrm{O}\right), 1620(\mathrm{C}=\mathrm{N}), 547(\mathrm{M}-\mathrm{N})$ \\
$(12)$ & 15.3 & Dia & 28785 & $3477\left(\mathrm{H}_{2} \mathrm{O}\right), 1618(\mathrm{C}=\mathrm{N}), 543(\mathrm{M}-\mathrm{N})$ \\
\hline
\end{tabular}

\section{${ }^{I} H$ NMR Spectra}

${ }^{1} \mathrm{H}$ NMR spectra of the Schiff base ligands and their diamagnetic $\mathrm{Zn}(\mathrm{II})$ complexes were recorded in DMSO- $\mathrm{d}_{6}$. ${ }^{1} \mathrm{H}$ NMR spectral data of the Schiff base ligands $\left(\mathrm{L}^{1}\right)-\left(\mathrm{L}^{3}\right)$ and their diamagnetic $\mathrm{Zn}(\mathrm{II})$ complexes are provided in the experimental section. ${ }^{1} \mathrm{H}$ NMR spectra of the ligand $\left(\mathrm{L}^{1}\right)$ showed $\left(\mathrm{CH}_{3}\right)$ protons on azomethine linkage and aromatic ring, and $\left(\mathrm{CH}_{2}\right)$ protons of ethylene group at 2.18, 2.35 and $3.82 \mathrm{ppm}$ as a singlet, respectively. The $\mathrm{R}^{1}$ and $\mathrm{R}^{4}$ protons of aromatic ring were observed at 6.75 and $7.14 \mathrm{ppm}$ as a doublet, respectively. Ligand $\left(\mathrm{L}^{2}\right)$ displayed $\left(\mathrm{CH}_{3}\right)$ protons on azomethine linkage and $\left(\mathrm{CH}_{2}\right)$ protons of ethylene group at 2.16 and $3.87 \mathrm{ppm}$ as a singlet, respectively. The $\left(\mathrm{NH}_{2}\right)$ protons present in the ligand $\left(\mathrm{L}^{2}\right)$ were observed at $5.33 \mathrm{ppm}$ as a singlet. The $\mathrm{R}^{2}$ and $\mathrm{R}^{5}$ protons of aromatic ring were observed at 7.05 and $7.67 \mathrm{ppm}$ as a doublet, and $\mathrm{R}^{3}$ and $\mathrm{R}^{4}$ protons appeared at 6.97 and $7.39 \mathrm{ppm}$ as a triplet, respectively. The $\left(\mathrm{CH}_{3}\right)$ protons on azomethine linkage and aromatic ring, and $\left(\mathrm{CH}_{2}\right)$ protons of ethylene group present in the ligand $\left(\mathrm{L}^{3}\right)$ were observed at 2.24, 2.32 and $3.74 \mathrm{ppm}$ as a singlet, respectively. The $\mathrm{R}^{2}$ protons of aromatic ring were found at $6.75 \mathrm{ppm}$ as double doublet, and $\mathrm{R}^{4} \& \mathrm{R}^{5}$ protons appeared at 7.14-7.37 ppm as a doublet, respectively. The coordination of the azomethine $(\mathrm{C}=\mathrm{N})$ nitrogen was confirmed by the downfield shifting of all the protons signal in their $\mathrm{Zn}(\mathrm{II})$ complexes. This downfield shifting of proton in $\mathrm{Zn}$ (II) complexes was attributed to the discharging of electronic cloud towards the $\mathrm{Zn}$ (II) ion. A singlet peak was observed in all the $\mathrm{Zn}$ (II) complexes at $10.5 \mathrm{ppm}$ due to the presence of water molecules confirming the coordination of the ligands with the $\mathrm{Zn}$ metal atom. All other protons underwent downfield shift by $0.06-0.14 \mathrm{ppm}$ owing to the increased conjugation on complexation with the zinc metal atom. Thus, the number of proton calculated from the integration curves [26] and obtained values of the expected $\mathrm{CHN}$ analysis agreed well with each others.

${ }^{13}$ C NMR Spectra

${ }^{13} \mathrm{C}$ NMR spectra of the Schiff bases and their diamagnetic $\mathrm{Zn}(\mathrm{II})$ complexes were recorded in DMSO- $\mathrm{d}_{6}$. The ${ }^{13} \mathrm{C}$ NMR spectral data are reported along with their possible assignments in the experimental section and all the carbons were found in the expected regions. The ${ }^{13} \mathrm{CNMR}$ spectra of the Schiff base ligands $\left(\mathrm{L}^{1}\right)-\left(\mathrm{L}^{3}\right)$ showed characteristic azomethine $(\mathrm{C}=\mathrm{N})$ carbons at $162.9-163.7 \mathrm{ppm}$. The $\left(\mathrm{CH}_{3}\right)$ carbons on azomethine linkage, $\left(\mathrm{CH}_{2}\right)$ carbons of ethylene group and $(\mathrm{CH})$ carbons of aromatic rings were observed at 17.5-18.5, 20.9-21.6 and 114.4-159.3 ppm, respectively. Downfield shifting of the azomethine carbons from $\delta 162.9$ $163.7 \mathrm{ppm}$ in the free ligands to $163.7-164.4 \mathrm{ppm}$ in its $\mathrm{Zn}$ (II) complexes was due to shifting of electronic density towards the $\mathrm{Zn}(\mathrm{II})$ ion. Similarly, all carbons of methyl groups and aromatic rings being near to the coordination sites also showed downfield shifting by $0.5-1.1 \mathrm{ppm}$ due to the increased conjugation and coordination with the metal atoms. The downfield shifting also confirmed the coordination of the azomethine to the zinc metal atom. Moreover, the presences of the number of carbons are well in agreement with the expected values [27]. Furthermore, the conclusions drawn from these studies present further support to the modes of bonding discussed in their IR and ${ }^{1} \mathrm{H}$ NMR spectra.

\section{Mass Spectra}

The mass fragmentation pattern of the ligands $\left(\mathrm{L}^{1}\right)-\left(\mathrm{L}^{3}\right)$ followed the cleavage of $\mathrm{C}=\mathrm{N}$ (exocyclic) and $\mathrm{C}=\mathrm{C}$ bonds. The mass spectral data and the most stable fragmentation values of the ligands were depicted in experimental section. All the ligands showed pronounced molecular ion peaks. The data of the Schiff bases shown by mass spectra strongly confirmed the formation of the ligands possessing proposed structures and also, their bonding pattern.

\section{Molar Conductances and Magnetic Measurements}

Molar conductance studies of the complexes were carried out in DMF. The data of molar conductances (13.1-15.3 ohm ${ }^{1} \mathrm{~cm}^{2} \mathrm{~mol}^{-1}$ ) of metal(II) complexes (1)-(12) showed that these complexes were non electrolytic [28] in nature. The magnetic moment (B.M) values of all the metal(II) complexes, (1)-(12) were measured at room temperature. The observed magnetic moment values of $\mathrm{Co}(\mathrm{II})$ complexes were found in the range of 4.36-4.53 B.M indicating the $\mathrm{Co}(\mathrm{II})$ complexes as high-spin suggesting three unpaired electrons in an octahedral environment [29]. The Ni(II) complexes displayed magnetic moment values in the range of 3.33-3.57 B.M indicative of two unpaired electrons per $\mathrm{Ni}$ (II) ion suggesting these complexes to have an octahedral [30] geometry. The measured magnetic moment values 1.891.95 B.M for $\mathrm{Cu}(\mathrm{II})$ complexes are indicative of one unpaired electron per $\mathrm{Cu}(\mathrm{II})$ ion for $\mathrm{d}^{9}$-system suggesting octahedral [31] geometry. All the $\mathrm{Zn}$ (II) complexes were found to be diamagnetic [32] as expected. 


\section{Electronic Spectra}

The electronic spectra of $\mathrm{Co}(\mathrm{II})$ complexes generally showed [33] three absorption bands in the region 8627-8699, 17736-17859 and 29674-29744 $\mathrm{cm}^{-1}$ which may be assigned to $4 \mathrm{~T}_{1} \mathrm{~g} \rightarrow 4 \mathrm{~T}_{2} \mathrm{~g}(\mathrm{~F}), \quad 4 \mathrm{~T}_{1} \mathrm{~g} \rightarrow 4 \mathrm{~A}_{2} \mathrm{~g}(\mathrm{~F}) \quad$ and $\quad 4 \mathrm{~T}_{1} \mathrm{~g} \rightarrow 4 \mathrm{Tg}(\mathrm{P})$ transitions respectively, and are suggestive of octahedral geometry around the Co(II) ion. The electronic spectral data of $\mathrm{Ni}(\mathrm{II})$ complexes showed [25] the bands in the region 8639-8659, 17679-17694 and 25716-257710 $\mathrm{cm}^{-1}$ assigned respectively, to the d-d transitions of $3 \mathrm{~A}_{2} \mathrm{~g}(\mathrm{~F}) \rightarrow 3 \mathrm{~T}_{2} \mathrm{~g}(\mathrm{~F})$ and $3 \mathrm{~A}_{2} \mathrm{~g}(\mathrm{~F}) \rightarrow 3 \mathrm{~T}_{1} \mathrm{~g}(\mathrm{~F})$. Also a strong band due to metal to ligand charge transfer was appeared at $29767-29816 \mathrm{~cm}^{-1}$. The electronic spectra of all the $\mathrm{Cu}(\mathrm{II})$ complexes exhibited [34] absorption bands in the region at $8670-8735$ and 17437$17543 \mathrm{~cm}^{-1}$ which may be assigned to the transitions $2 \mathrm{Eg} \rightarrow 2 \mathrm{~T}_{2} \mathrm{~g}$. The high energy band at $29673-29731 \mathrm{~cm}^{-1}$ was due to forbidden ligand to metal charge transfer. On the basis of electronic spectra, octahedral geometry around the $\mathrm{Cu}$ (II) ion was suggested. The $\mathrm{Zn}$ (II) complexes did not show any $\mathrm{d}-\mathrm{d}$ transition thus showing diamagnetic nature and their spectra were dominated only by a charge transfer band [35] at $28715-28785 \mathrm{~cm}^{-1}$.

\section{Biological Screening}

\section{Antibacterial Bioassay (in-vitro)}

The newly synthesized Schiff bases $\left(\mathrm{L}^{1}\right)-\left(\mathrm{L}^{3}\right)$ and their metal(II) complexes (1)-(12) have been subjected for the screening of their in-vitro antibacterial activity against Escherichia coli, Streptococcus faecalis, Pseudomonas aeruginosa, Klebsiella pneumoniae, Staphylococcus aureus and Bacillus subtilis bacterial strains according to standard procedure [18] and results were reported in Table 3. The obtained results were compared with those of the standard drug streptomycin. The synthesized ligand $\left(\mathrm{L}^{1}\right)$ showed a significant $(16-20 \mathrm{~mm})$ activity against all bacterial strains except Bacillus subtilis strain which possessed moderate (15 $\mathrm{mm})$ activity. Ligand $\left(\mathrm{L}^{2}\right)$ displayed overall significant (17$20 \mathrm{~mm})$ activity against all strains. Ligand $\left(\mathrm{L}^{3}\right)$ demonstrated significant (16-18 mm) activity against Escherichia coli, Klebsiella pneumoniae, Staphylococcus aureus and Bacillus subtilis, and moderate (11-14 $\mathrm{mm}$ ) activity was observed by
Streptococcus faecalis, Pseudomonas aeruginosa. The metal complexes (1)-(4), (6)-(8) and (10)-(12) displayed overall significant $(16-25 \mathrm{~mm})$ activity against all the bacterial strains. Compound (5) exhibited a significant (17-21 mm) activity against Streptococcus faecalis, Pseudomonas aeruginosa, Klebsiella pneumoniae and Bacillus subtilis bacterial strains except Escherichia coli and Staphylococcus aureus which possessed moderate (12-14 mm) activity. Beside this, the compound (9) exhibited a significant (16-20 $\mathrm{mm}$ ) activity against all bacterial strains except Streptococcus faecalis which possessed moderate $(14 \mathrm{~mm})$ activity. The data reported in Table 3 clearly indicated that $\left(\mathrm{L}^{2}\right)$ showed overall good bacterial activity as compared to other two ligands. The $\mathrm{Zn}(\mathrm{II})$ complexes (4) and (8) of $\left(\mathrm{L}^{2}\right)$ were found to be the most active complexes. The metal(II) complexes showed [36] higher activity results upon complexation rather than their uncomplexed Schiff bases.

Table 3. Antibacterial Bioassay of Ligands and their Metal(II) Complexes (Zone of Inhibition, $\mathrm{mm}$ ).

\begin{tabular}{lllllllll}
\hline & \multicolumn{9}{c}{ Gram-negative } & \multicolumn{7}{c}{ Gram-positive } \\
\hline Compounds & (a) & (b) & (c) & (d) & (e) & (f) & (SA) & Average \\
\hline$\left(\mathrm{L}^{1}\right)$ & 18 & 16 & 16 & 20 & 16 & 15 & 1.83 & 16.83 \\
$\left(\mathrm{~L}^{2}\right)$ & 19 & 17 & 18 & 20 & 18 & 17 & 1.17 & 18.16 \\
$\left(\mathrm{~L}^{3}\right)$ & 18 & 11 & 14 & 16 & 17 & 18 & 2.73 & 15.66 \\
$(1)$ & 22 & 24 & 19 & 19 & 22 & 22 & 2.58 & 21.33 \\
$(2)$ & 18 & 16 & 24 & 22 & 16 & 18 & 3.29 & 19.00 \\
$(3)$ & 24 & 17 & 19 & 21 & 23 & 16 & 3.22 & 20.00 \\
$(4)$ & 24 & 22 & 25 & 24 & 22 & 23 & 1.21 & 23.33 \\
$(5)$ & 14 & 19 & 21 & 19 & 12 & 17 & 3.41 & 17.00 \\
$(6)$ & 19 & 20 & 19 & 24 & 23 & 22 & 2.14 & 21.16 \\
$(7)$ & 24 & 23 & 21 & 24 & 22 & 23 & 1.17 & 22.83 \\
$(8)$ & 25 & 22 & 24 & 25 & 22 & 23 & 1.38 & 23.5 \\
$(9)$ & 20 & 14 & 17 & 18 & 17 & 16 & 2.00 & 17.00 \\
$(10)$ & 18 & 22 & 21 & 19 & 18 & 20 & 1.63 & 19.66 \\
$(11)$ & 17 & 18 & 24 & 16 & 24 & 19 & 3.50 & 19.66 \\
$(12)$ & 16 & 20 & 18 & 18 & 17 & 23 & 2.50 & 18.66 \\
SD & 30 & 27 & 28 & 29 & 29 & 28 & 1.05 & 28.5 \\
\hline
\end{tabular}

(a) E. Coli (b) S. Faecalis (c) P. Aeruginosa (d) K. Pneumoniae (e) S. Aureus (f) B. Subtilis; SD: Standard Drug; weaker $=0-10 \mathrm{~mm}$, moderate $=11-15$ $\mathrm{mm}$, above $15 \mathrm{~mm}=$ significant, $\mathrm{SA}=$ Statistical Analysis

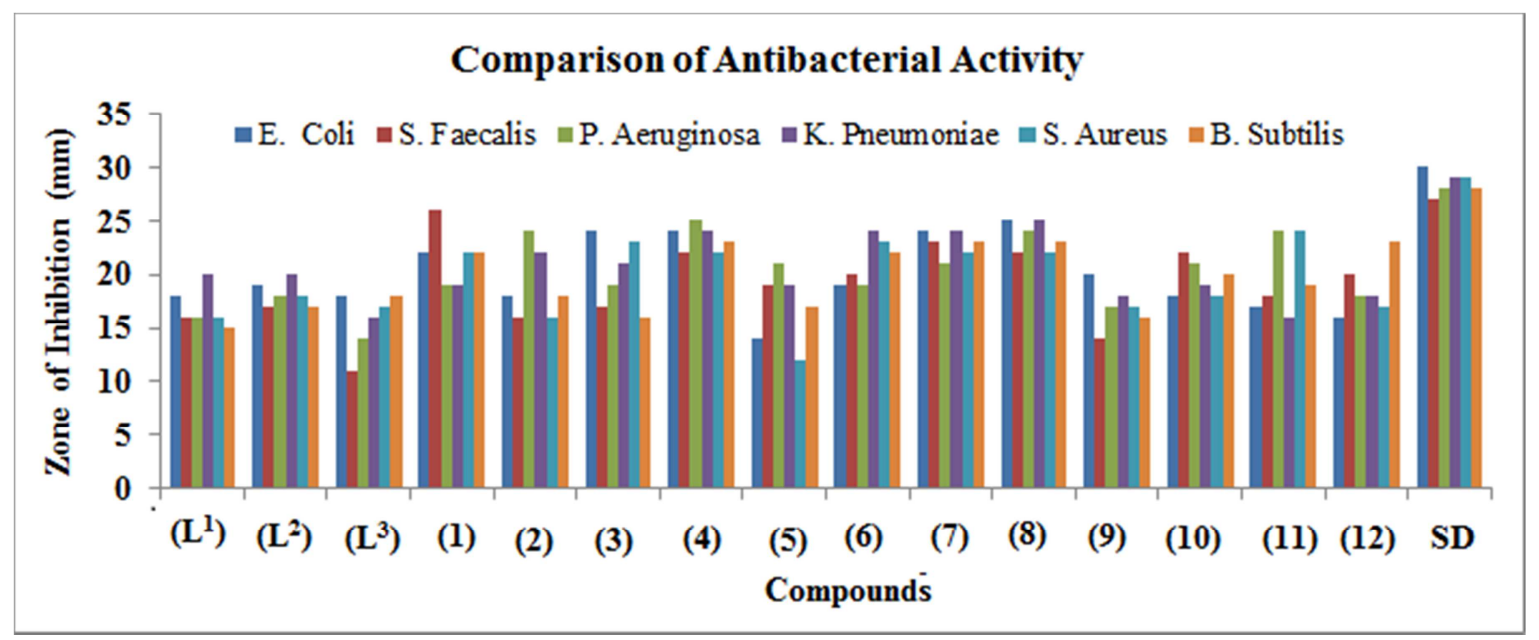

Figure 1. Comparison of Antibacterial Activity of Schiff bases versus Metal(II) Complexes. 


\section{Antifungal Bioassay (in-vitro)}

The antifungal screening of all compounds was carried out against Trichophyton mentogrophytes, Epidermophyton floccosum, Aspergillus niger, Microscopum canis, Fusarium culmorum and Trichophyton schoenleinii fungal strains Table 4 according to the literature protocol [19]. The results of inhibition were compared with the results of standard drugs, miconazole and amphotericin B. Ligand $\left(\mathrm{L}^{1}\right)$ displayed significant (55-58\%) activity against Trichophyton mentogrophytes and Fusarium culmorum fungal strain, moderate (37-46\%) against Epidermophyton floccosum, Microscopum canis, and Trichophyton schoenleinii and, but showed weaker (25\%) activity against Aspergillus niger. Ligand, $\left(\mathrm{L}^{2}\right)$ possessed significant (54-63\%) activity against Trichophyton mentogrophytes, Epidermophyton floccosum, Aspergillus niger, Microscopum canis, and moderate (4649\%) activity against Fusarium culmorum and Trichophyton schoenleinii. However, $\left(\mathrm{L}^{3}\right)$ showed significant (54-55\%) activity against Aspergillus niger and Fusarium culmorum, and moderate (43-45\%) activity against Trichophyton mentogrophytes and Microscopum canis. Moreover, a weaker (24\%) activity was shown by Epidermophyton floccosum but Trichophyton schoenleinii did not any activity. The compound (1), (4) and (6)-(8) showed overall significant (54-80\%) activity against all fungal strains. Similarly, compound (2) possessed significant (59-77\%) activity against Trichophyton mentogrophytes, Epidermophyton floccosum and Trichophyton schoenleinii, and moderate (38-43\%) activity against Aspergillus niger, Microscopum canis and Fusarium culmorum. As well, the compound (3) displayed significant (54-69\%) activity against Epidermophyton floccosum, Microscopum canis and Trichophyton schoenleinii, moderate (38-45\%) against Trichophyton mentogrophytes and Fusarium culmorum and also weaker (20\%) activity against Aspergillus niger. The compound (5) similarly, possessed significant $(55-70 \%)$ activity against Epidermophyton floccosum, Aspergillus niger, Microscopum canis and Fusarium culmorum fungal strains except Trichophyton mentogrophytes, and Trichophyton schoenleinii strains which observed moderate (35-40\%) activity. The compound (9) showed significant (54-62\%) activity against Trichophyton mentogrophytes, Aspergillus niger and Microscopum canis, and moderate (39-51\%) activity against Epidermophyton floccosum, Fusarium culmorum and Trichophyton schoenleinii. Similarly, the compound (10) displayed significant (54-68\%) activity against Trichophyton mentogrophytes, Aspergillus niger, Microscopum canis and Fusarium culmorum, moderate (35\%) against Epidermophyton floccosum and also weaker (20\%) activity against Trichophyton schoenleinii. On the other hand, the compound (11) presented significant (60$71 \%$ activity against Trichophyton mentogrophytes, Epidermophyton floccosum and Microscopum canis fungal strains, and other strains such as Aspergillus niger and Fusarium culmorumii showed moderate (35-52\%) activity. Also weaker $(18 \%)$ activity was observed against
Trichophyton schoenleinii. Like the same way, the compound (12) showed significant activity (57-65\%) against Trichophyton mentogrophytes, Aspergillus niger, Microscopum canis and Fusarium culmorum and the strain Epidermophyton floccosum displayed moderate (40\%) activity and weaker (14\%) activity was shown by Trichophyton schoenleinii. It is obvious from the data reported in Table 4 that $\left(\mathrm{L}^{2}\right)$ showed overall good fungal activity as compared to other two ligands. The Ni(II) complex (6) of $\left(\mathrm{L}^{2}\right)$ was found to be the most active complex. The metal(II) complexes showed enhanced [37] activity results rather than their uncomplexed Schiff bases due to complexation.

Table 4. Antifungal Bioassay of Ligands and their Metal(II) Complexes (\% inhibition).

\begin{tabular}{|c|c|c|c|c|c|c|c|c|}
\hline Compounds & (a) & (b) & (c) & (d) & (e) & (f) & (SA) & Average \\
\hline$\left(\mathrm{L}^{1}\right)$ & 58 & 46 & 25 & 41 & 55 & 37 & 13.19 & 43.66 \\
\hline$\left(\mathrm{L}^{2}\right)$ & 56 & 59 & 63 & 54 & 43 & 49 & 07.16 & 54.00 \\
\hline$\left(\mathrm{L}^{3}\right)$ & 45 & 24 & 54 & 43 & 55 & 00 & 21.22 & 36.83 \\
\hline (1) & 75 & 62 & 80 & 57 & 54 & 73 & 10.61 & 66.83 \\
\hline (2) & 59 & 77 & 38 & 43 & 43 & 64 & 15.18 & 54.00 \\
\hline (3) & 45 & 56 & 20 & 69 & 38 & 54 & 16.90 & 47.00 \\
\hline (4) & 81 & 70 & 63 & 78 & 62 & 57 & 09.52 & 68.50 \\
\hline (5) & 40 & 61 & 70 & 57 & 35 & 55 & 12.97 & 53.00 \\
\hline (6) & 72 & 77 & 65 & 69 & 70 & 75 & 04.32 & 71.33 \\
\hline (7) & 59 & 66 & 54 & 74 & 80 & 78 & 10.58 & 68.50 \\
\hline (8) & 71 & 55 & 63 & 73 & 79 & 75 & 08.80 & 69.33 \\
\hline (9) & 57 & 46 & 62 & 54 & 51 & 39 & 08.17 & 51.50 \\
\hline (10) & 54 & 35 & 65 & 55 & 68 & 20 & 18.40 & 49.50 \\
\hline (11) & 52 & 38 & 71 & 50 & 60 & 18 & 18.40 & 48.16 \\
\hline (12) & 57 & 40 & 63 & 59 & 65 & 14 & 19.59 & 49.66 \\
\hline SD & A & B & $\mathrm{C}$ & D & $\mathrm{E}$ & $\mathrm{F}$ & - & - \\
\hline
\end{tabular}

(a) T. Mentogrophytes (b) E. Floccosum (c) A. Niger (d) M. Canis (e) F. Culmorum (f) T.Schoenleinii; weaker $=0-30 \%$, moderate $=31-54 \%$, 55$100 \%=$ significant, $\mathrm{SA}=$ Statistical Analysis

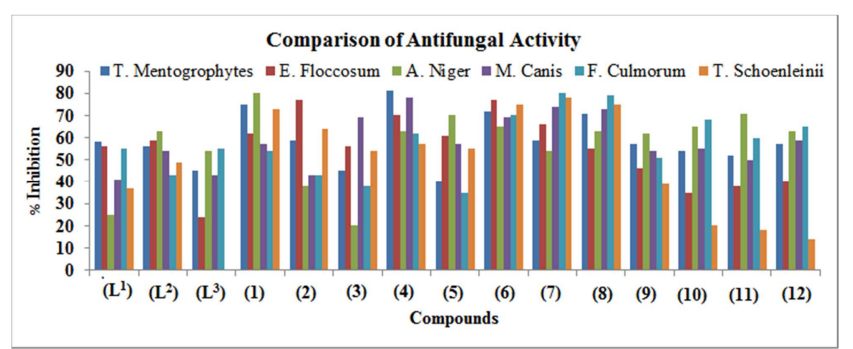

Figure 2. Comparison of Antifungal Activity of Schiff bases versus Metal(II) Complexes.

\section{Minimum Inhibitory Concentration (MIC)}

The synthesized ligands and their transition metal(II) complexes showing promising antibacterial activity (above $80 \%$ ) were selected for MIC studies and obtained results are reported in Table 5. The antibacterial results indicated that the metal(II) complexes (1)-(4), (6)-(8) and (10)-(12) were found to display activity more than $80 \%$, therefore, these complexes were selected for their MIC screening. The MIC values of these compounds fall in the range 23.11 to 48.43 $\mu \mathrm{g} / \mathrm{mL}$. Amongst these, the compound (4) was found to be the most active possessing maximum inhibition $23.11 \mu \mathrm{g} / \mathrm{mL}$ 
against bacterial strain P. Aeruginosa.

Table 5. Minimum Inhibitory Concentration ( $\mu \mathrm{g} / \mathrm{mL})$ of the Selected Compounds (1)-(4), (6)-(8) and (10)-(12) against Selected Bacteria.

\begin{tabular}{|c|c|c|c|c|c|c|}
\hline No. & E. Coli & S. Faecalis & P.Aeruginosa & K. Pneumoniae & S. Aureus & B. Subtilis \\
\hline (1) & - & 45.26 & - & - & - & - \\
\hline (2) & - & - & 34.16 & - & - & - \\
\hline (3) & 25.17 & - & - & - & - & - \\
\hline (4) & 30.16 & 39.24 & 23.11 & 43.22 & - & - \\
\hline (6) & - & - & - & 28.67 & - & - \\
\hline (7) & 36.35 & 45.22 & - & 40.54 & - & 46.62 \\
\hline (8) & 48.43 & 32.67 & 23.79 & 35.11 & - & 27.82 \\
\hline (10) & - & 33.21 & - & - & - & - \\
\hline (11) & - & - & 35.67 & - & 44.26 & - \\
\hline (12) & - & - & - & - & - & 32.11 \\
\hline
\end{tabular}

\section{Conclusions}

Three bidentate N, O donor type Schiff base ligands were prepared by the condensation reaction of ethylene-1,2diamine with 3,4,6-trimethylacetophenone, 2aminoacetophenone and 2,4-dimethylacetophenone in 1:2 molar ratio These ligands were further complexed with transition metals to produce their new metal complexes. Elemental analysis and spectral data of the uncomplexed ligands and their metal(II) complexes were found to be in good agreement with their structures, indicating high purity of all the compounds with octahedral geometry. All ligands and their metal complexes were screened for antimicrobial activity. The results of antimicrobial activity indicated that metal complexes have significantly higher activity than their uncomplexed ligands. This higher activity might be due to chelation process which reduces the polarity of metal ion by coordinating with ligands.

\section{Conflict of Interests}

The authors declare that there is no conflict of interests regarding the publication of this paper and are responsible for the contents and writing of the paper.

\section{Acknowledgements}

Provision of research facility and analysis at the premier research center, the H.E.J. Research Institute of Chemistry, International Center for Chemical and Biological Sciences, University of Karachi, Karachi is highly acknowledged.

\section{References}

[1] Z. H. Chohan, M. Hanif, Design, synthesis, and biological properties of triazole derived compounds and their transition metal complexes, J. Enz. Inhib. Med. Chem. 25, 737, (2010).

[2] M. M. Abd-Elzaher, Spectroscopic characterization of some tetradentate Schiff bases and their complexes with nickel, copper and zinc, J. Chin. Chem. Soc., 48, 153, (2001).

[3] Z. H. Chohan, S. H. Sumrra, Metal based biologically active compounds: Design, synthesis, and antibacterial/antifungal/cytotoxic properties of triazolederived Schiff bases and their oxovanadium(IV) complexes, Eur. J. Med. Chem. 45, 2739, (2010).

[4] A. H. El-Masry, H. H. Fahmy, S. H. A. Abdelwahed, Synthesis and Antimicrobial Activity of Some New Benzimidazole Derivatives, Molecules. 5, 1429, (2000).

[5] A. A. Jarrahpour, M. Motamedifar, K. Pakshir, N. Hadi, M. Zarei,Synthesis of novel azo Schiff bases and their antibacterial and antifungal activities, Molecules,9, 815, (2004).

[6] S. A. Kabeer, M. A. Baseer, N. A. Mote, Synthesis and antimicrobial activity of some Schiff bases from benzothiazoles, Asian J. Chem. 13, 496, (2001).

[7] V. B. Arion, E, Reisner, M. Fremuth, M. A. Jokupec, B. K. Keppler, V. Y. Kukushkin, A. J. L. Pombeiro. Synthesis, X-ray Diffraction Structures, Spectroscopic Properties, and in vitro Antitumor Activity of Isomeric (1H-1,2,4Triazole)Ru(III) Complexes, Inorg. Chem. 42, 6024, (2003).

[8] J. M. Lazic, L. Vucicevic, S. Grguric Sipka et al., Synthesis and in vitro anticancer activity of octahedral platinum(IV) complexes with cyclohexyl-functionalized ethylenediamineN,N'-diacetate- type ligands, Chem Med Chem, 5, 881, (2010).

[9] M. A. Hussein, R. M. Shaker, M. A. Ameen, M. F. Mohammed. Synthesis, anti-inflammatory, analgesic, and antibacterial activities of some triazole, triazolothiadiazole, and triazolothiadiazine derivatives, Arch. Pharm. Res. 34, 1239, (2011).

[10] X. S. Cui, C. Jing, K. Y. Chai, J. S. Lee, Z. S. Quan, Synthesis and anticonvulsant evaluation of 3-substituted-4-(4hexyloxyphenyl)4H-1,2,4-triazoles, Med. Chem. Res. 18, 49, (2009).

[11] M. Kritsanida, A. Mouroutsou, P. Marakos, N. Pouli, S. Papakonstantinou-Garoufalias, C. Pannecouque C et al, Farmaco 57, 253, 2002.

[12] S. Manfredini, C. B. Vicentini, M. Manfrini, N. Bianchi, C. Rutigliano, C. Mischiati, R. Gambari, Pyrazolo-triazoles as light activable DNA cleaving agents, Bioorg. Med. Chem. 8, 2343, (2000).

[13] G. Turan-Zitouni, Z. A. Kaplancikli, K. Erol, F. S. Kilic. Synthesis and analgesic activity of some triazoles and triazolothiadiazines, Farmaco 54, 218, (1999). 
[14] N. P. Singh, A. N. Srivastava, Physico-chemical and biological studies of $\mathrm{Cu}$ (II), $\mathrm{Co}$ (II) and $\mathrm{Ni}$ (II) complexes of an $\mathrm{N}_{4}$ coordinating ligand derived from the Schiff base of diacetyl with ethylenediamine and benzoic acid, J. Serb. Chem. Soc. 77, 627, (2012).

[15] R. A. Shiekh, I. A. Rahman, M. A. Malik, S. M. Masudi, N. Luddin, Synthesis, spectral, electrochemical and biological studies of nitrogen donor macrocyclic ligand and its transition metal complexes, Int. J. Electrochem. Sci. 7, 12829, (2012).

[16] S. Schertl, R. W. Hartmann, C. Batzl-Hartmann, G. Bernhardt, T. Sprub, K. Beckenlehner, M. Koch, R. Krauser, R. Schlemmer, R. Gust, H. Schönenberger. [1, 2$\operatorname{Bis}(2$ 6-difluoro-3-hydroxyphenyl)ethylenediamine]platinum(II) Complexes, Compounds for the Endocrine Therapy of Breast Cancer - Mode of Action II: Contribution of Drug Inactivation, Cellular Drug Uptake and Sterical Factors in the Drug-Target Interaction to the Antitumor Activity., Archiv der Pharmazie. 337, 335, (2004).

[17] I. P. Tripath, M. M. Kumar, T. Ruchita, M. Chinmayi, K. Arti, S. Laxmikant, D. Atul, S. U. Kumar, P. K. Bhihari. Res. J. Chem. Sci. 4, 13, (2014).

[18] A. U. Rahman, M. I. Choudhary, W. J. Thomsen. "Bioassay techniques for drug development". (Harwood Academic, The Netherlands 14, 2001).

[19] M. S. Mohamed, M. M. Kamel, E. M. Kassem, N. Abotaleb, S. I. A. El-moez, M. F., Ahmed, Novel 6,8-dibromo$4(3 \mathrm{H})$ quinazolinone derivatives of anti-bacterial and antifungalactivities, Eur J. Med Chem, 45 (8), 3311, (2010).

[20] J. L. McLaughlin, C. J. Chang, D. L. Smith. "Bench Top" bioassays for the discovery of bioactive natural products: an update, structure and chemistry (part-B). In: Atta-ur-Rahman (ed) Studies in natural products chemistry. (Elsevier Science, The Netherlands, 1991).

[21] Z. H. Chohan, S. H. Sumrra, Synthesis, characterization and biological studies of oxovanadium(IV) complexes with triazole-derived Schiff bases, App. Organomet. Chem. 24, 122, (2010).

[22] B. S. Holla, M. Mahalinga, M. S. Karthikeyan, B. Poojary, P. M. Akberali, N. S. Kumari, Synthesis, characterization and antimicrobial activity of some substituted 1,2,3-triazoles, Eur. J. Med. Chem. 40, 1173, (2005).

[23] S. H. Sumrra, Z. H. Chohan, Metal based new triazoles: Their synthesis, characterization and antibacterial/antifungal activities. Spectrochim. Acta A: Mol. Biomol. Spectr. 98, 53, (2012).

[24] M. Hanif, Z. H. Chohan, Design, spectral characterization and biological studies of transition metal(II) complexes with triazole Schiff bases, Spectrochim. Acta A: Mol. Biomol. Spectr. 104, 468, (2013).

[25] S. H. Sumrra, M. Ibrahim, S. Ambreen, M. Imran, M. Danish, F. S. Rehmani. Synthesis, Spectral Characterization, and Biological Evaluation of Transition Metal Complexes of
Bidentate N, O Donor Schiff Bases, Bioinorg. Chem. Appl. 2014, 1, (2014).

[26] R. A. Nyquist. Interpreting Infrared, Raman and Nuclear Magnetic Resonance Spectra. (Academic Press, 2001).

[27] M. Levitt, Spin Dynamics: Basics of Nuclear Magnetic Resonance. (John Wiley and Sons, 2001).

[28] J. Liu, B. Wu, B. Zhang, Y. Liu, Synthesis and characterization of metal complexes of $\mathrm{Cu}(\mathrm{II}), \mathrm{Ni}(\mathrm{II}), \mathrm{Zn}(\mathrm{II})$, $\mathrm{Co}(\mathrm{II}), \mathrm{Mn}(\mathrm{II})$ and $\mathrm{Cd}(\mathrm{II})$ with tetradentate schiff bases, Turk. J. Chem. 30, 41, (2006).

[29] S. Sarkar, K. Dey. Synthesis and spectroscopic characterization of some transition metal complexes of a new hexadentate $\mathrm{N}_{2} \mathrm{~S}_{2} \mathrm{O}_{2}$ Schiff base ligand, Spectrochimica. Act A. 62, 383, (2005).

[30] K. Serbest, H. Kayi, E. Mustafa, K. Sancak, I. Degirmencioglu, $\mathrm{Ni}(\mathrm{II}), \mathrm{Cu}(\mathrm{II})$, and $\mathrm{Zn}(\mathrm{II})$ complexes of tetradentate schiff base containing two thiadiazoles units: Structural, spectroscopic, magnetic properties, and molecular modeling studies, Heteratom Chem. 19, 700, (2008).

[31] R. M. El-Shazly, G. A. A. Al-Hazmi, S. E. Ghazya, M. S. ElShahawi, A. A. El-Asmya, Spectroscopic,thermaland electrochemical studies on some nickel(II) thiosemicarbazone complexes, Spectrochimica Act A. 61, 243, ( 2005).

[32] S. Chandra, L. K. Gupta. EPR, mass, IR, electronic, and magnetic studies on copper (II) complexes of semicarbazones and thiosemicarbazones, Spectrochimica Act A. 61, 269, (2005).

[33] H. Temel, U. Cakir, B. Otludil, H. G. Ugras. Synthesis, spectral and biological studies of $\mathrm{Mn}(\mathrm{II}), \mathrm{Ni}(\mathrm{II}), \mathrm{Cu}(\mathrm{II})$, and $\mathrm{Zn}(\mathrm{II})$ complexes with a tetradentate Schiff base ligand. Complexation studies and the determination of stability constants (Ke), Syn. React. Inorg. Metal-Org. Chem. 31(8), 1323, (2001).

[34] D. L. Pavia, G. M. Lampman, G. S. Kriz, J. R. Vyvyan. Spectroscopy (Crooks/Cole, 2007).

[35] W. E. Estes, D. P. Gavel, W. B. Hatfield, D. Hodgson, Magnetic and structural characterization of dibromo- and dichlorobis(thiazole)copper(II), Inorg. Chem. 17, 1415, (1978).

[36] S. H. Sumrra, Z. H. Chohan, Antibacterial and antifungal oxovanadium(IV) complexes of triazole-derived Schiff bases, Med. Chem. Res. 22, 3934, (2013).

[37] Sajjad H. Sumrra, Muhammad Hanif, Zahid H. Chohan, Muhammad Safwan Akram, Javeed Akhtar, Saad M. AlShehri, Metal based drugs: design, synthesis and in-vitro antimicrobial screening of $\mathrm{Co}(\mathrm{II}), \mathrm{Ni}(\mathrm{II}), \mathrm{Cu}(\mathrm{II})$ and $\mathrm{Zn}(\mathrm{II})$ complexes with some new carboxamide derived compounds: crystal structures of $\mathrm{N}$-[ethyl (propan-2yl)carbamothioyl]thiophene-2-carboxamide and its copper(II) complex, J. Enz. Inhib. Med. Chem., DOI: 10.3109/14756366.2015.1050011 (2016). 